\title{
The growth of three teak (Tectona grandis) clones and its effect on wood properties
}

\author{
GUDIWIDAYANTO SAPTO PUTRO ${ }^{1}$, SRI NUGROHO MARSOEM ${ }^{2, \bullet}$, JOKO SULISTYO ${ }^{2}$, \\ SURYO HARDIWINOTO ${ }^{2}$ \\ ${ }^{1}$ Faculty of Forestry, Institut Pertanian Intan Yogyakarta. J1 Magelang Km 5.6, Mlati, Sleman 55284, Yogyakarta, Indonesia \\ ${ }^{2}$ Faculty of Forestry, Universitas Gadjah Mada. J1. Agro No. 1, Bulaksumur, Sleman 55281, Yogyakarta, Indonesia. Tel./fax.: +62-274-550541. \\ vemail: snmarsoem@ugm.ac.id
}

Manuscript received: 30 March 2020. Revision accepted: 28 May 2020.

\begin{abstract}
Putro GS, Marsoem SN, Sulistyo J, Hardiwinoto S. 2020. The growth of three teak (Tectona grandis) clones and its effect on wood properties. Biodiversitas 21: 2814-2821. Various clones of superior teak (Tectona grandis L. f.) trees have recently been introduced in several land conditions. A study was conducted on three different clones of superior teak known as Jati Unggul Nusantara (JUN) growing in Paliyan, Gunungkidul, Yogyakarta, Indonesia. Two different ages of those clones were observed their growth rate and its wood properties. Strip plot design was applied to the treatment of tree age (five and eight-year-old) and clone types (D14, F35, and F21 clones). Tree growth was measured on 300 trees, meanwhile, annual growth rate and wood properties were measured on 18 trees. The result showed that at five-year-old as well as eight-year-old, the D14 clone has the best growth performance with diameter of $14.6 \pm$ $1.80 \mathrm{~cm}$ and $20.5 \pm 2.54 \mathrm{~cm}$ and height of $9.8 \pm 1.72 \mathrm{~m}$ and $15.2 \pm 2.13 \mathrm{~m}$ respectively. The growth rate negatively correlated with temperature and had no significant correlation to the precipitation. Different clones and tree age significantly affect the variability of fiber length, green specific gravity, and heartwood proportion. The clone of D14 produced the highest-fiber length, green specific gravity, and heartwood proportion $(1.111 \mathrm{~mm} ; 0.50$ and $17.7 \%)$ at five-year-old trees and $(1.156 \mathrm{~mm} ; 0.54$ and $49.0 \%)$ at eight-years-old.
\end{abstract}

Keywords: Fiber length, growth rate, heartwood, specific gravity, superior clone

\section{INTRODUCTION}

Teak (Tectona grandis L. f.) has been known as highvalue timber for its strength, fine grain, artistic appearance and durability (Marsoem 2013), resistant to termites and fungal attacks (Lukmandaru 2011; Lacret et al. 2012) and easy workability (Hallett et al. 2011). Teak is traditionally planted at rotation of 60-80 years. The increase of teak wood demand has caused an imbalance between supply and demand of the wood (Thulasidas and Bailleres 2017). In the last decade efforts to increase the availability (standing stock) of teak wood have been carried out by establishment of fast growth teak tree plantations. A number of Jati Unggul Nusantara (JUN, hereinafter referred to as JUN teak) clones (a fast-growing-teak) have been developed using vegetative propagation techniques. They have been established in several forest resorts and in the Paliyan resort they currently have reached the age of eight years. However, information relating to the properties of the wood is still limited.

The growth rate and the properties of the wood produced are greatly influenced by internal factors such as genetic traits and tree physiological conditions (Tardieu et al. 2014; Latutrie et al. 2015), and also external factors such as rainfall and temperature (Castagneri et al. 2017; Shmulsky and Jones 2019). Wood from young plantations with fast-growing species is commonly to be dominated by lower quality wood (Hadiyane et al. 2018). In this aspect, the growth rate acceleration is apprehended to disadvantage in terms of wood quality. Moya and Munoz (2010) who examined specific gravity (SG) of eight fast-growing wood species from plantations forest found that each tree species showed different results and could be divided into three specific gravity groups, namely three trees with higher $\mathrm{SG}$, two trees with the same SG, and three trees with lower SG then those of their nature trees.

Some other studies reported that the increase at growth rate of teak trees is often followed by changes in the properties of wood as reported by Zahabu et al. (2015). However, some other studies showed that growth rate did not significantly affect the properties of wood in some species of fast-growing tropical and sub-tropical trees (Kojima et al. 2009; Naji et al. 2011; Malik and Abdelgadir 2015; Pertiwi et al. 2017).

The planting of JUN teak which is considered as having fast growth rate character should, therefore, be studied their growth and wood properties more thoroughly. By doing this, we can expect to utilize wood from young plantation forest properly (Marsoem et al. 2015; Rocha et al. 2019). In studying wood properties in the stem, it is also important to observe the variability among the growth rings (Olivar et al. 2015). The purpose of this study is to find out the growth of three JUN teak clones at five and eight-year-old, in relation to wood properties considering precipitation and temperature. 


\section{MATERIALS AND METHODS}

\section{Study area}

The research was conducted on Jati Unggul Nusantara (JUN) teak stand in Menggoro and Kepek Forest Management Resorts located in Paliyan Sub-district, Gunungkidul District, Yogyakarta Province, Indonesia. This location is shown in Figure 1.

\section{Procedures}

Strip-plot design was used to determine the occurrence of variations in growth rates and wood properties. The observation was conducted on three different JUN teak clones (D14, F35, and F21clones) and two age groups (five and eight-year-old). Teak trees were planted at a distance of $3 \times 3 \mathrm{~m}^{2}$, two rows for each clone. The planting block has a relatively flat topography with a slope of $0-8 \%$. This area including karst area with nutrient-poor black grumusol soil types. Measurement of tree diameter and height was carried out with $50 \%$ sampling intensity of the 600 trees population. At each treatment, 50 tree samples were measured so that a total of 300 tree samples were used.

Meanwhile, to observe the relationship between tree growth rate and the properties of wood formed, three trees replication were measured per unit treatment so that a total of 18 tree samples were used. Each sample tree was cut down and cut into discs with a thickness of two $\mathrm{cm}$ at a position $1.3 \mathrm{~m}$ from the base of the trunk (dbh). The width of each ring from pith to bark in the transverse surface was first measured, and each disc was then divided, on the north side of the stem, into two pieces of radial direction with a width of two $\mathrm{cm}$ (for measuring specific gravity of wood) and $1 \mathrm{~cm}$ (for measurement of fiber length). Each piece of wood was cut based on the thickness of the tree ring from the first to the last of growth ring.

The testing of wood specific gravity was carried out according to the British Standard 373 (Ozigi et al. 2018) testing for small clear wood specimens, with modifications in sample dimensions to the width of the tree ring, while fiber length measuration was conducted according to the IAWA (Firmino et al. 2019). The proportion of heartwood was determined by measuring the area of heartwood to the total area of cross-section of the stem on the dbh.

To find out the effect of microclimate changes on tree growth rate, two independent variables were used namely rainfall and temperature. Microclimate data from 2010 to 2017 were obtained from Meteorology Climatology and Geophysics Council. The growth rate represented by the width of tree ring was used as a dependent variable. The samples were determined randomly from the existing JUN teak stand population.

\section{Data analysis}

Correlation analysis was used to find out relationship between microclimate changes and tree growth rates, while the relationship between the height and diameter of the trees was observed by simple regression analysis. Variability of wood properties between clone types, tree rings, and tree age was analyzed by analysis of variance with $95 \%$ reliability. Sources of variation that showed a significant effect were further analyzed by using Duncan's multiple range test (DMRT).

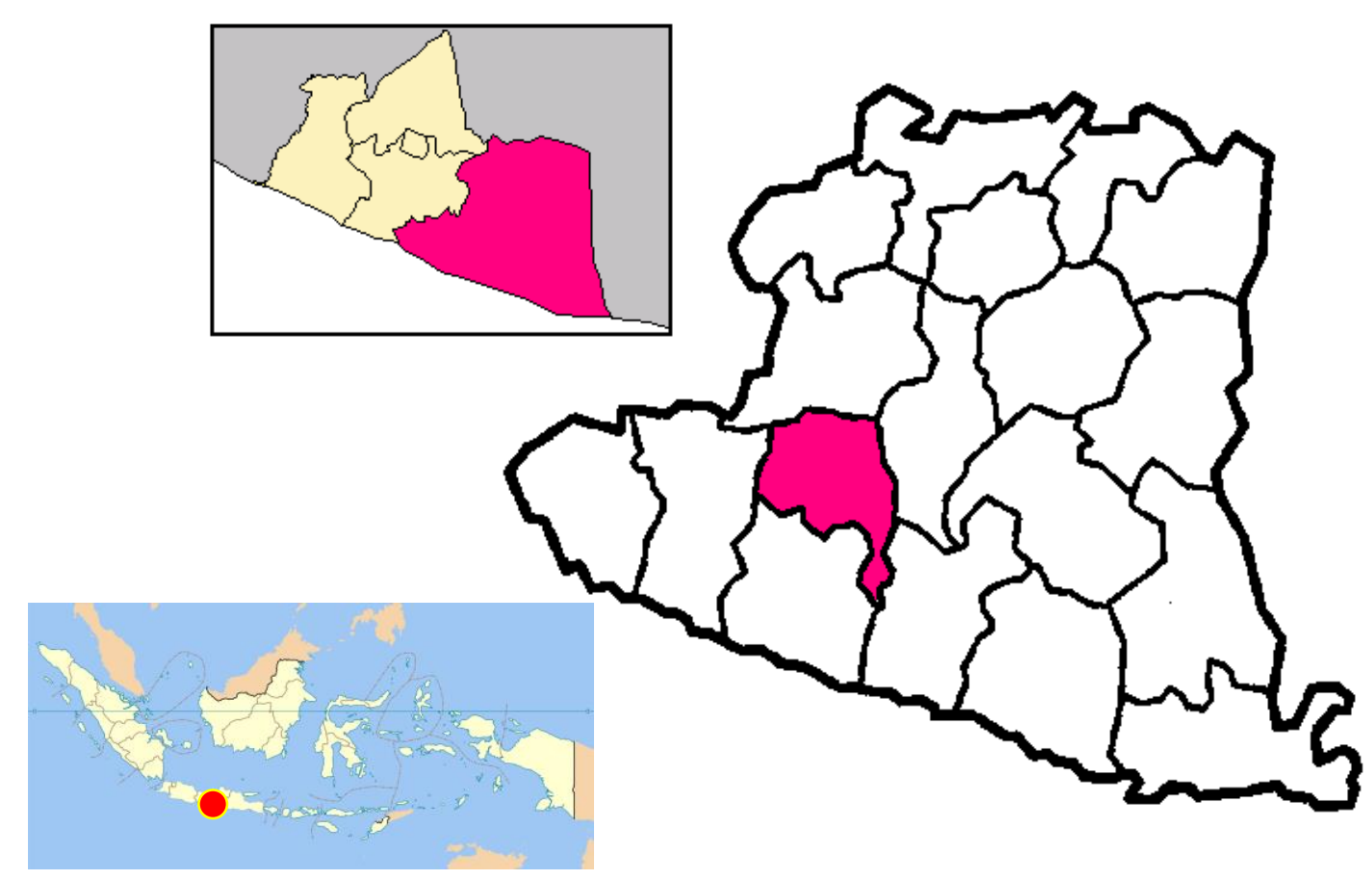

Figure 1. Location of Jati Unggul Nusantara stands in Sub-district of Paliyan, District of Gunungkidul, Yogyakarta Province, Indonesia ( $\left.7^{\circ} 56^{\prime} 40,6^{\prime \prime} \mathrm{S} ; 110^{\circ} 32^{\prime} 59,8^{\prime \prime} \mathrm{E}\right)$ 


\section{RESULTS AND DISCUSSION}

\section{Height and diameter growth}

Table 1 shows the average height and diameter of three JUN teak clones at five and eight years old. These values are then used to calculate annual growth. Average annual growth is obtained by dividing total growth at the age of the observed tree by the age of the tree. The result showed that at five-years-old, the annual tree height (growth) increment was in the range of 1.288 $\pm 0.31-1.968 \pm 0.22 \mathrm{~m}$. This value is lower than the results of Muttaqin et al. (2019) in Cogreg, Bogor which achieved high growth of $3.7 \mathrm{~m}$ per year. This difference result is most likely due to the differences in growing sites, planting methods, and microclimate at the study site. Statistical analysis and DMRT showed that JUN clones significantly affected tree growth rates. The tree height of D14 was 23\% and 53.1\% higher than that of F35 and F21 respectively. However, although the diameter growth sequence of the three clones also showed the same trend, the DMRT of the increase in diameter growth of clones D14 and F35 did not show any significant difference.

Interestingly, D14 clones at both 5 and 8 years of age show a higher annual height $(9.8 \pm 1.72$ and $15.3 \pm 2.13 \mathrm{~m}$ respectively) and diameter $(14.6 \pm 1.80$ and $20.5 \pm 2.54 \mathrm{~m}$ respectively) increment than the JPP superior teak grown in Cepu (Rahmadwiati et al. 2012), while F35 only shows a higher annual diameter increase and at F21 only occurs at 5 years old. Further comparisons show that all observed clones showed a much higher diameter increment than the "ordinary" teak from East Timor of 0.43-0.73 cm (Sousa et al. 2012) and from the same resort of Paliyan of 1.06-1.60 $\mathrm{cm}$ (Marsoem 2013). Some other comparisons show that all observed clones seem to show a lower annual height and diameter increment than three-year-old teak grown in Bogor (Widiatmaka et al. 2015). This phenomenon may be caused by the condition of the soil where the clones grow. All of these clones are planted in soil with karst conditions that put stress on plant growth (Rachmawati et al. 2018). This finding shows that the tree growth performance of three clones, both height, and diameter, are influenced by the genetic traits of trees inherited from the parents as shown in a previous study (Chaix et al. 2011; Goh et al. 2013).

The relationship between tree height and diameter is an important element in describing forest stands condition (Mugasha et al. 2013) and is an important measure of stand stability (Vospernik et al. 2010). Further observations in 5 and 8 year-old-trees are provided in Figure 2.

In Figure 2.A, it appears that in a 5 year-old-tree, all clones show a relatively good linear relationship with the equation $\mathrm{y}=0.7202 \mathrm{x}-0.7055$ for clone $\mathrm{D} 14, \mathrm{y}=0.5902 \mathrm{x}+$ 0.2590 for clone $F 21$, and $y=0.4180 x+2.1918 x$ for clone F35. The height predictive ability of F21 clone is almost the same as those of D14 clone, however, D14 clone shows the largest increase in diameter compared to the other two clones, having $\mathrm{r}^{2}$ value of 0.5887 .

Table 1. The height and diameter of three clones of JUN, analysis of variance and further test results

\begin{tabular}{|c|c|c|c|c|c|c|c|}
\hline \multirow{2}{*}{ Parameters } & \multirow{2}{*}{$\begin{array}{c}\text { Age } \\
(\mathrm{yr})\end{array}$} & \multicolumn{6}{|c|}{ Clones* } \\
\hline & & D14 & & F35 & & F21 & \\
\hline \multirow{2}{*}{ Height $(\mathrm{mm})^{*}$} & 5 & $9.8 \pm 1.72$ & $\mathrm{a}$ & $8.0 \pm 1.60$ & $\mathrm{~b}$ & $6.4 \pm 1.53$ & $\mathrm{c}$ \\
\hline & 8 & $15.3 \pm 2.13$ & $\mathrm{x}$ & $11.2 \pm 3.30$ & $\mathrm{y}$ & $9.0 \pm 1.80$ & $\mathrm{z}$ \\
\hline \multirow[t]{2}{*}{ Diameter $(\mathrm{cm})^{*}$} & 5 & $14.6 \pm 1.80$ & $\mathrm{a}$ & $13.9 \pm 2.61$ & $\mathrm{a}$ & $10.4 \pm 1.60$ & $\mathrm{~b}$ \\
\hline & 8 & $20.5 \pm 2.54$ & $\mathrm{x}$ & $17.8 \pm 1.60$ & $\mathrm{y}$ & $15.4 \pm 1.53$ & z \\
\hline
\end{tabular}

Note: * significant. Means with same letter in each parameter is not significantly different

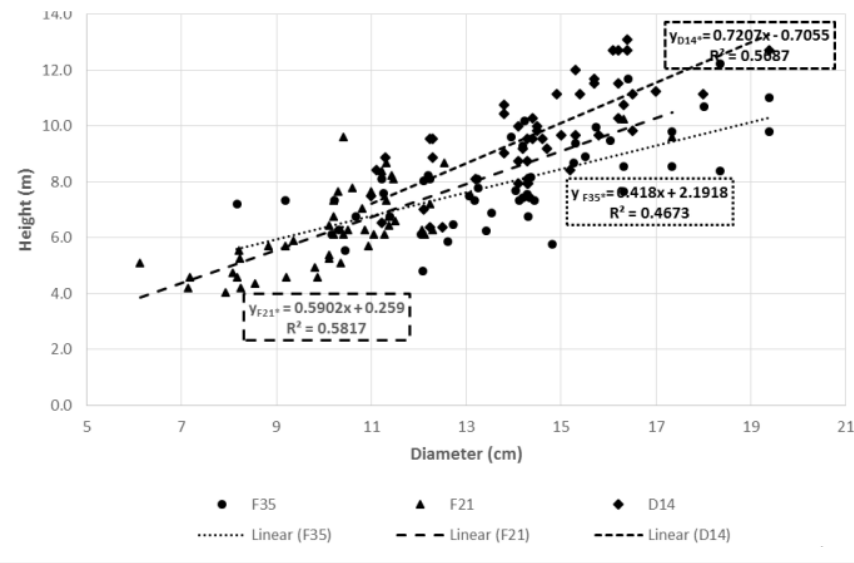

A

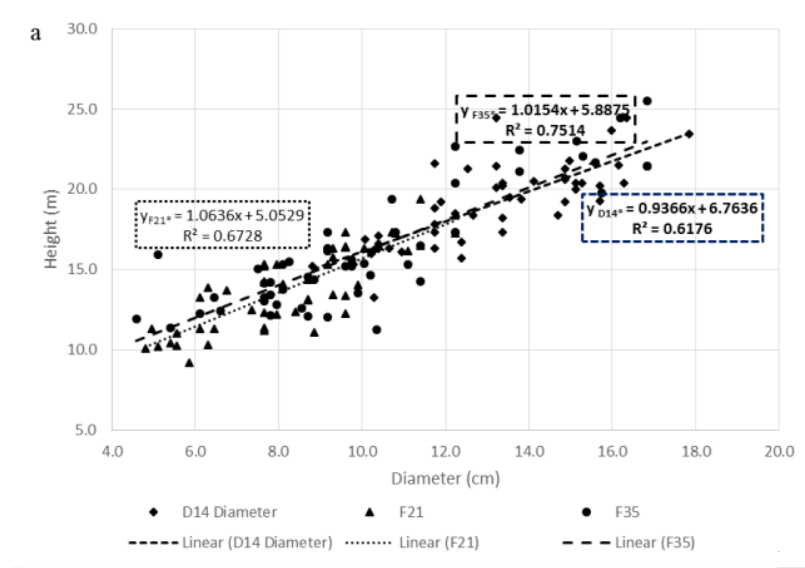

B

Figure 2. The relationship between height and diameter. A. 5-years-old-trees, B. 8-years-old-trees of JUN 


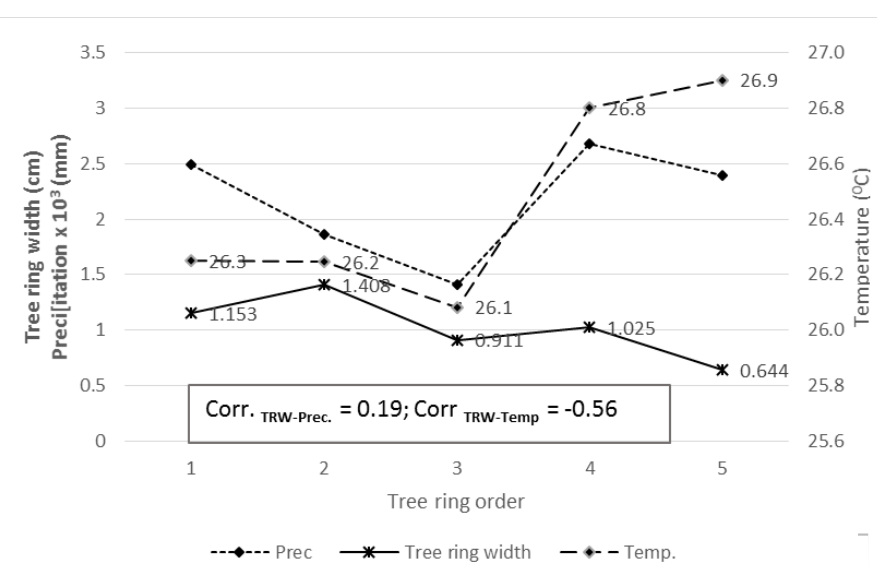

A

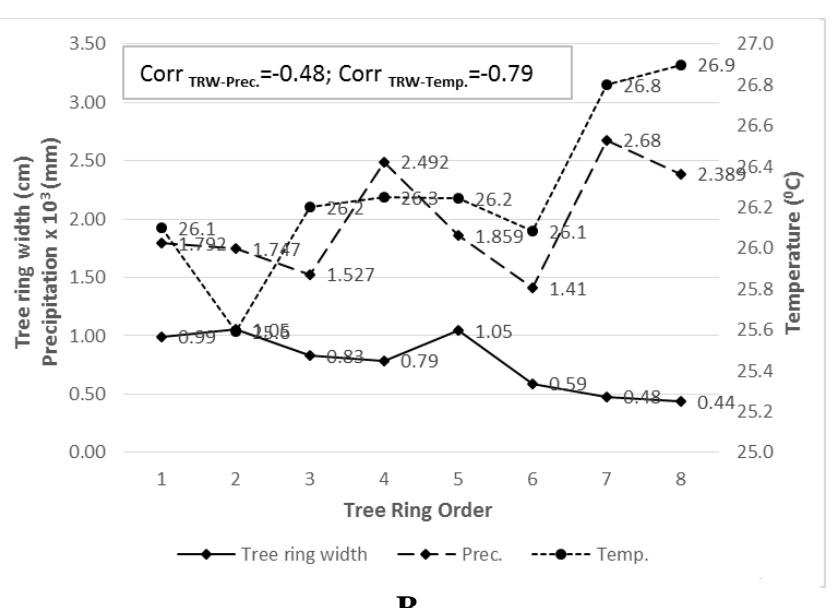

B

Figure 3. The relationship between growth rate to precipitation and temperature. A. five-years-old, B. eight-years-old

The relationship between tree height and diameter of D14 clone at age of eight gives an $r^{2}$ value of 0.6176 , a coefficient determination value that is higher than fiveyear-old trees, but that value is still lower than the value indicates by clones F35 and F21. Since the measurement of height is more time consuming and has several additional sources of error while height-diameter equation in this study shows a rather strong relationship then until the age of eight years the height of the trees can be predicted by only measuring the diameter of the tree. Figure 2 indicates that the increase in height is linearly followed by the increase in diameter. The linear relationship between tree height and diameter was also occurred on Chamaecyparis obtusa (Sumida et al. 2013) and also on teak stand in Nigeria (Shamaki et al. 2016).

Besides soil conditions, growth variability is also affected by environmental factors (Shmulsky and Jones 2019) such as rainfall (Goh et al. 2015) and temperature (Toledo et al. 2011; Begum et al. 2013). The effect of rainfall and temperature on the growth of three JUN clones in 5 and 8 years are shown in Figure 3 respectively. The results indicate that there was no significant correlation in the relationship between fluctuations of precipitation and tree growth in both five and eight-year-old stands. The unclear effect of precipitation on the growth ring width is presumably due to lack of clarity in the season differences during the observation period. Previous study on teak in Myanmar also showed non-significant relationship between tree ring and the annual total rainfall (Hlaing et al. 2014). According Kaosa-Ard (1981) teak grows best and reaches large dimensions in a warm-moist tropical climate with rainfall ranging from 1,270-3,800 $\mathrm{mm}$ per annum, while the annual rainfall during the observation in the site was $1410-2690 \mathrm{~mm}$.

Kaosa-Ard (1981) reported that the most favorable conditions for the growth of teak are between $22^{\circ} \mathrm{C}$ and $27^{\circ} \mathrm{C}$. In this study, the effect of temperature on the width of growth ring can be seen in Figure 3 where the effect of temperature is more visible than the influence of the precipitation. The result shows that JUN trees of five, as well as eight years old, show a similar response to the variation of the temperature. The correlation values $r=-0.56$ (5-year-old-trees) and $\mathrm{r}=-0.79$ (8-year-old-trees) in this study belong to the moderate and high classification, and were higher than the correlation value of 0.24 obtained from the study on the middle age teak plants grown in community forest conducted by Marsoem (2013). A similar finding is reported by Hlaing et al. (2014) who found more pronounced relations in young teak plants than the older age one. It showed that temperature range has reached the optimum level for supporting growth. Therefore the increasing temperature in the planting site of JUN teak stand will beyond optimum point and tend to decrease the tree growth rate.

\section{Heartwood proportion}

The result in Table 2 shows that heartwood is already present in the five-year-old JUN tree. Among the three clones observed, clone D14 from the five-year-old JUN tree showed the highest proportion followed by clones F35 and F21 but all three showed no significant difference. Increasing the age of trees from five to eight years has increased the proportion of heartwood by $62.4 \%$ to $165.7 \%$. At the age of eight years, clone D14 showed the highest proportion of heartwood that was significantly different from JUN clones F35 and F21. It can be seen that the D14 clone had a heartwood formation rate far above the other clones. This is evident that although at the early formation (five-year-old) was not significantly different at eight-year-old of JUN teak tree, the heartwood formation increased sharply and showed noticeable difference with the heartwood at five-year-old. An increase in the proportion of heartwood with increasing diameter was also reported by Tewari and Mariswamy (2013) and Yang et al. (2020) in dominant, co-dominant, and depressed tree classes. Meanwhile, it was not reported in other previous studies that short rotation teak has similar (Anish et al. 2015) or lower heartwood proportion than long rotation teak (Rizanti et al. 2018). 
Table 2. The wood properties of three clones JUN teak, analysis of variance and further test results

\begin{tabular}{|c|c|c|c|c|c|c|c|}
\hline \multirow{2}{*}{ Parameters } & \multirow{2}{*}{ Age } & \multicolumn{6}{|c|}{ Clones* } \\
\hline & & D14 & & F35 & & F21 & \\
\hline \multirow[t]{2}{*}{ Fiber length $(\mathrm{mm})^{*}$} & 5 & $1.110 \pm 0.095$ & $\mathrm{a}$ & $1.067 \pm 0.103$ & $\mathrm{a}$ & $0.936 \pm 0.101$ & $\mathrm{~b}$ \\
\hline & 8 & $1.133 \pm 0.113$ & $\mathrm{x}$ & $0.989 \pm 0.112$ & $\mathrm{y}$ & $1.078 \pm 0.111$ & $\mathrm{z}$ \\
\hline \multirow[t]{2}{*}{ Green specific gravity* } & 5 & $0.504 \pm 0.021$ & $\mathrm{a}$ & $0.454 \pm 0.026$ & $\mathrm{~b}$ & $0.450 \pm 0.010$ & $\mathrm{~b}$ \\
\hline & 8 & $0.541 \pm 0.028$ & $\mathrm{x}$ & $0.485 \pm 0.028$ & $\mathrm{y}$ & $0.473 \pm 0.020$ & $\mathrm{y}$ \\
\hline \multirow[t]{2}{*}{ Heartwood proportion $(\%)^{*}$} & 5 & $17.7 \pm 1.03$ & a & $16.1 \pm 1.84$ & $\mathrm{a}$ & $13.6 \pm 2.31$ & $\mathrm{a}$ \\
\hline & 8 & $49.0 \pm 2.22$ & $\mathrm{x}$ & $26.6 \pm 2.64$ & $\mathrm{y}$ & $25.8 \pm 1.76$ & $\mathrm{y}$ \\
\hline
\end{tabular}

Note: * significant. Means with same letter in each parameter is not significantly different

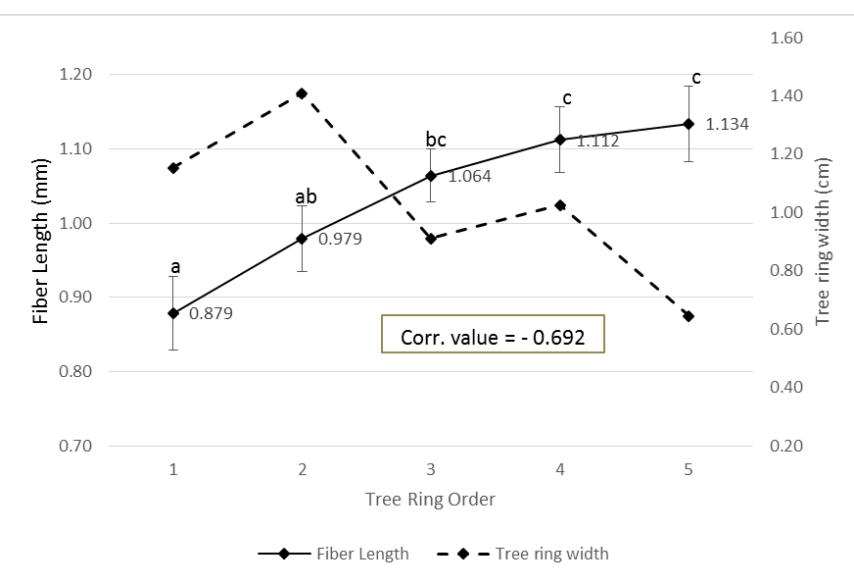

A

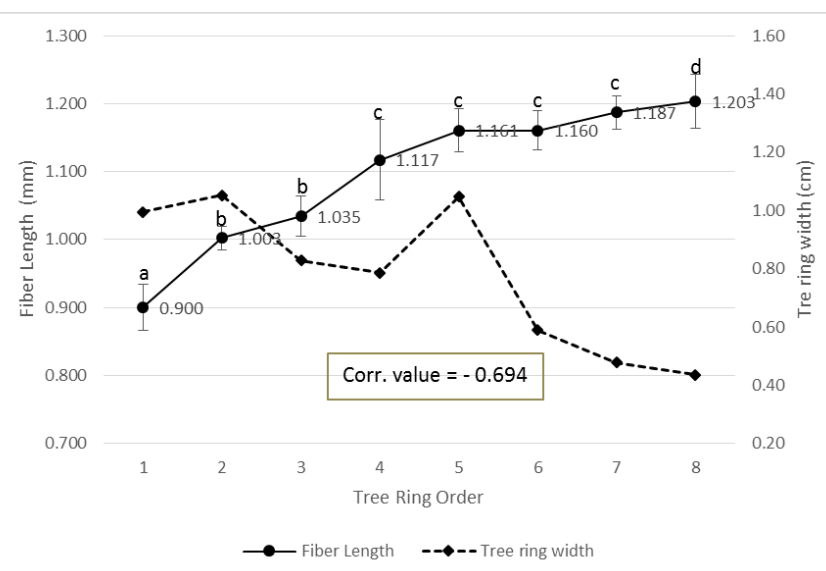

B

Figure 4. The distribution of fiber length and its correlation with annual growth rate. A. five-years-old; B. eight-years-old

\section{Fiber length}

Table 2 shows that, at five years old, the fiber length of D14 clone was almost the same as F35, but the length of both fibers was significantly longer than the F21 clone. At the age of eight, there were significant differences in fiber length among the three clones. The length of the D14 clone fibers was the longest, followed by the F21 and F35 clones with shorter fiber lengths $5.1 \%$ and $14.6 \%$ respectively. This also showed that the increase in length of F21 clone fibers at the age of five to eight-year was much higher than that of F35 clone. The magnitude of the effect of the clones was also reported by Damayanti et al. (2019) that different clones that grow in the same site conditions produced different fiber lengths.

The fiber produced by clone D14, both at the age of five and eight years, was longer than the seven-year-old JPP superior teak fiber with a length of 1,015 mm (Basri and Wahyudi 2013) or Cepu and Madiun clones of JPP teak with fiber length of 0.77 and $0.86 \mathrm{~mm}$ respectively (Yulianti et al. 2011). Obviously, JUN teak trees, in addition to having better growth than superior teak JPP stands, are also able to produce longer fibers. However, it should be noted that the fiber length of D14 clone was still lower compared to the 12-year-old of nine Perhutani teak clones which produced fiber length of 1,38-1.48 mm (Hidayati et al. 2014).
In the radial direction, the fiber length distribution of each tree ring was shown in Figure 4. At the age of five and eight years, fiber length tends to increase sharply from the first to the third or fourth tree ring followed by a slight increase up to the eighth tree ring. The effect of differences on the stem to the fiber length produced has been reported by Rizki and Fernandez (2015) on Shorea leprosula. In addition, an increase in fiber length was also reported by Darmawan et al. (2013) on the initial growth of Perhutani short rotation teak and loJayacal teak from community forests, as well as by Kojima et al. (2009) on Gmelina arborea trees. This pattern was similar to the characteristics of juvenile wood which was characterized by short fibers (Gryc et al. 2011) and experiences a progressive increase coincide with trees age until they reached a constant fiber length (Lachenbruch et al. 2011, Firmino et al. 2019). This showed that at the age of eight years, JUN teak trees still produced juvenile wood until they reach a constant fiber length.

Variability in fiber length had a close correlation to annual growth rates of the tree. The decrease in growth rate will be followed by an increase in fiber length, with the correlation coefficient including the middle class. Similar results were reported by Anish et al. (2015) that the slow growth of teak tended to be followed by an increase in the anatomical properties of wood, as well as the results study by Missanjo and Matsumura (2016) on young pine wood. 


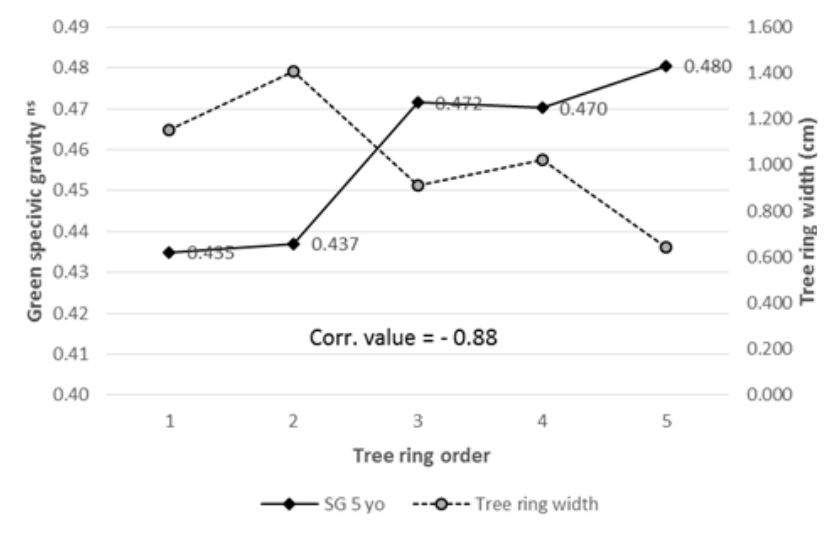

A

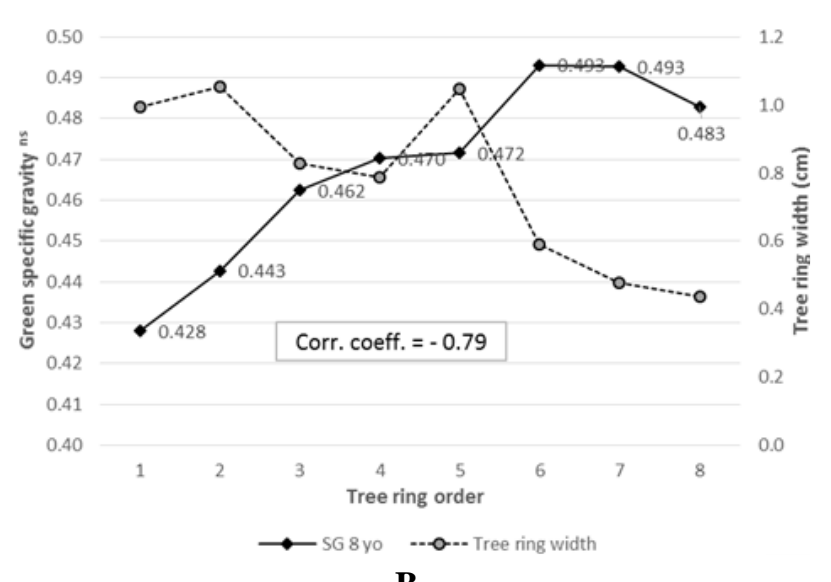

B

Figure 5. The variability of green specific gravity and its correlation to annual growth rate. A. five-years-old; B. eight-years-old; ns: non-significant

\section{Green specific gravity}

The different clones significantly influenced the green specific gravity. Clone D14 produced the highest specific gravity of wood which was $11.03 \%$ above F35 clone and $12.1 \%$ above F21 clone. While there was no significant difference between the specific gravity of wood produced by F35 and F21 clones. At eight-year-old, type of the clone had a significant effect on the green specific gravity of wood. Clone D14 produced the highest green specific gravity of wood followed significantly $12 \%$ and $15 \%$ by F35 and F21 respectively, while both of two clones were not significantly different. The high specific gravity of wood produced by D14 clone consistently shows the potential timber as raw material for construction purposes. The differences in specific gravity of wood resulting from clone effects were also reported by Hidayati et al. (2014) in nine clones of teak grown in Indonesia, Widiatmaka et al. (2019) in fast-growing teak, and Arce and Moya (2015) in 15 -year-old teak stands in Costa Rica. On the contrary, Yulianti et al. (2011) and Damayanti et al. (2019) did not find significant effect of the different clones on variation of specific gravity. In this case, specific gravity was more dominantly affected by growing sites than clone types. Specific gravity of D14 clone was higher than Mega teak aged 11 years $(0.50)$ and almost the same as conventional 14-year old teak which produced a specific gravity of 0.55 (Hidayati et al. 2016).

Figure 5 shows the variability of green specific gravity in the radial direction of JUN teak trees at the age of five and eight years. At five-year-old, specific gravity in successive growth ring from pith to bark increases sharply. At eight years old, this increase continued until sixth ring while on the seventh ring the specific gravity began to show a flat tendency. This was probably due to beginning of cambial maturation. This trend of increasing specific gravity was also reported by Mohamad and Marsoem (2007) on Acacia auriculiformis wood and Firmino et al. (2019) on Carapa guianensis wood. But the opposite results were obtained from the study of Kojima et al. (2009) in Gmelina arborea species. This shows the differences in the patterns of wood specific gravity that might occur among species as reported by Rodriguez et al. (2016).

Tree growth of JUN teak corresponded to the tree ring width as showed in Figure 5. It was found that the tree ring width tended to increase from the first to the second layer followed by the decreasing of the width up to the end layer (the age of eight). Variability of specific gravity has a negative correlation with the width of tree ring, with a high coefficient value. This shows that growth rates play a role in determining specific gravity variability.

This finding confirms the substantial influence of the juvenile growth period on young age trees as revealed by Shmulsky and Jones (2019). In addition young teak plants (under 20 years old) have a percentage of $80-100 \%$ juvenile wood which decreases with increasing tree age. At a young age, the characteristics of wood change progressively, which then inclines the change rate until maturity period and is followed by fluctuations in the distribution pattern of specific gravity at the next age. Kojima et al. (2009) also reported the effect of the age of young plants on the maturity of wood formed on Gmelina arborea tree, where was not formed mature wood under 3.5-year-old trees. As shown in Figure 5, it can be seen that up to five or six-year-old tree still experiences a juvenile period shown by a large increase of specific gravity. Meanwhile, in the next period, the JUN tree began to show the maturation process until eight-years-old. Thus, JUN tree at eight-year-old does not yet produce mature wood. Optimum use of teak wood is carried out when the specific gravity value has reached a stable period. Further research is needed on JUN teak above the age of eight years to determine the beginning of this period.

Three JUN teak clones grown in Paliyan showed significantly different growth rates and wood properties. Clone D14 of JUN teak tree had the best growth performance with diameter and height $14.60 \mathrm{~cm}$ and 9.80 $\mathrm{m}$ at the five-year-old and $20.50 \mathrm{~cm}$ and $15.20 \mathrm{~m}$ at the eight-year-old respectively. JUN teak tree growth had a negative correlation with temperature but did not have a 
significant correlation with precipitation fluctuations with correlation coefficient of- 0.56 and 0.19 at the age of five years and- 0.79 and- 0.48 at the age of eight years. Differences in clones and tree age significantly affected the variability of fiber length, green specific gravity, heartwood proportion. The highest fiber length, green specific gravity, and heartwood proportion were obtained on D14 clone with the values of $1.111 \mathrm{~mm} ; 0.50$ and $17.7 \%$ at five-year-old trees, and $1.156 \mathrm{~mm} ; 0.54$ and $49.0 \%$ at eight-year-old respectively. Distribution of green specific gravity and fiber length in JUN teak tree stem was more determined by an increase of tree age and including the juvenile period.

\section{ACKNOWLEDGEMENTS}

The author expresses sincere thanks to the research funders of Direktorat Riset dan Pengabdian Masyarakat Direktorat Jendral Penguatan Riset, Teknologi dan Pendidikan Tinggi with the agreement number 060/HBLIT/IV/2017. We thank the Committee of Workshop and Clinic Improving the Quality of Research, Research Capacity, and Research Program November 6-8, 2017 in Yogyakarta for the help of publication article writing techniques. We also thank the Chief of Forest Management Unit in Yogyakarta Special Region who granted permission for the harvesting of thirty teak trees. The authors are indebted to the Chief of Meteorology Climatology and Geophysics Council for providing climatic data.

\section{REFERENCES}

Anish MC, Anoop EV, Vishnu R, et al. 2015. Effect of growth rate on wood quality of teak (Tectona grandis L. f.): a comparative study of teak grown under differing site quality conditions. Intl Indian Acad Wood Sci 12 (1): 81-88.

Arce N, Moya R. 2015. Wood characterization of adult clones of Tectona grandis growing in Costa Rica. Cerne 21 (3): 353-362.

Basri E, Wahyudi I. 2013. Wood basic properties of Jati Plus Perhutani from different ages and their relationships to drying properties and qualities. J Penelit Has Hutan 31 (2): 93-102. [Indonesian]

Begum S, Nakaba S, Yamagishi Y, et al. 2013. Regulation of cambial activity in relation to environmental conditions: understanding the role of temperature in wood formation of trees. Physiol Plant 147 (1): 46-54

Castagneri D, Fonti P, Arx G, Carrer M. 2017. How does climate influence xylem morphogenesis over the growing season? Insights from long-term intra-ring anatomy in Picea abies. Ann Bot J 119 (6): $1011-1020$

Chaix G, Monteuuis O, Garcia C, et al. 2011. Genetic variation in major phenotypic traits among diverse genetic origins of teak (Tectona grandis L.f.) planted in Taliwas, Sabah, East Malaysia. Ann For Sci 68 (5): 1015-1026.

Damayanti R, Ilic J, Ozarska B, Pari G, Vinden P. 2019. Effect of clone and sites for wood properties of fast grown teak and determination of the best clone for next cultivation in teak plantation industries. IOP Conf. Ser.: Earth Environ Sci. DOI: 10.1088/17551315/359/1/012002

Darmawan W, Nandika D, Kartikasari R, et al. 2013. Juvenile and mature wood characteristics of short and long rotation teak in Java. Intl Assoc Wood Anat J 36 (4): 429-443.

Firmino AV, Vidaurre GB, Oliveira JT. et al. 2019. Wood properties of Carapa guianensis from floodplain and upland forests in Eastern Amazonia, Brazil. Sci Rep 9 (10641): 1-10.
Goh Dr, Bacilieri R, Chaix G, Monteuuis O. 2015. Growth variations and heritabilities of teak CSO-derived families and provenances planted in two humid tropical sites. Tree Genet Genomes 9 (5): 1329-1341.

Goh Dr, Japarudin Y, Alwi A, et al. 2013. Growth differences and genetic parameter estimates of 15 teak (Tectona grandis L.f.) genotypes of various ages clonally propagated by micro cuttings and planted under humid tropical conditions. Silvae Genet 62 (5): 196-206.

Gryc V, Vavrcik H, Horn K. 2011. Density of juvenile and mature wood of selected coniferous species. J For Sci 57: 123-130.

Hadiyane A, Dungani R, Dewi PD, Rumidatul A. 2018. Effect of chemical modification of jabon wood (Anthocephalus cadamba Miq.) on morphological structure and dimensional stability. J Biol Sci 18 (4): 201-207.

Hallett JT, Díaz-Calvo J, Villa-Castillo J, Wagner MR. 2011. Teak plantations: economic bonanza or environmental disaster? J For 109 (5): 288-292.

Hidayati F, Fajrin IT, Ridho MR, et al. 2016. Sifat fisika dan mekanika kayu Jati Unggul "Mega" dan kayu jati konvensional yang ditanam di Hutan Pendidikan Wanagama, Gunungkidul, Yogyakarta. J Ilmu Kehutan 10 (2): 98-107. [Indonesian]

Hidayati F, Ishiguri F, Iizuka K, et al. 2014. Among-clone variations of anatomical characteristics and wood properties in Tectona grandis planted in Indonesia. Wood Fiber Sci 46 (3): 385-393.

Hlaing ZC, Teplyakov VK, Thant NML. 2014. Influence of climate factors on tree-ring growth in teak (Tectona grandis L. f.) plantations in the Bago Yoma Range, Myanmar. For Sci Technol 10 (1): 40-45.

Kaosa-Ard A. 1981. Teak-its natural distribution and related factors. Nat Hist Bull Siam Soc 29: 55-74.

Kojima M, Yamamoto H, Marsoem SN, et al. 2009b. Effects of the lateral growth rate on wood quality of Gmelina arborea from 3.5-, 7-and 12 year-old plantations. Ann For Sci 66 (507): 502-507.

Kojima M, Yamamoto H, Ojio KOY, et al. 2009a. Effect of the lateral growth rate on wood properties in fast-growing hardwood species. $\mathrm{J}$ Wood Sci 55: 417-424.

Lachenbruch B, Moore JR, Evans R. 2011. Radial variation in wood structure and function in woody plants, and hypotheses for its occurrence. Tree Physiol 4: 121-164.

Lacret R, Varela RM, Molinillo JMG, Nogueiras C, Macias FA. 2012. Tectonoelins, ew or lignans from a bioactive extract of Tectona grandis. Phytochem Lett 5: 382-386.

Latutrie M, Mérian P, Picq S, et al. 2015. The effects of genetic diversity, climate and defoliation events on trembling aspen growth performance across. Can Tree Gen Genomes 11 (5): 1-14.

Lukmandaru G. 2011. Variability in the natural termite resistance of plantation teak wood and its relations with wood extractive content and color properties. J For Res 8 (1): 1817-31.

Malik MFE, Abdelgadir AY. 2015. Effect of growth rate on wood density of Eucalyptus camaldulensis wood of coppice origin grown in White Nile State Sudan. J For Prod Ind 4 (3): 86-93.

Marsoem SN, Setiaji F, Kim NH, et al. 2015. Fiber morphology and physical characteristics of Gigantochloa atter at three different ages and heights of culms for better utilization. J Korean Wood Sci Technol 43 (2): 145-155.

Marsoem SN. 2013. Studi mutu kayu jati di hutan rakyat gunungkidul: pengukuran laju pertumbuhan. J Ilmu Kehutan 7 (2): 108-122.

Missanjo E, Matsumura J. 2016. Radial variation in tracheid length and growth ring width of Pinus kesiya Royle ex Gordon in Malawi. Intl J Res Agric For 3 (1): 13-21.

Mohamad S, Marsoem SN. 2007. Karakteristik dan variasi sifat fisik kayu Acacia mangium Wild. pada beberapa jarak tanam dan kedudukan aksial-radial. J Pemuliaan Tanam Hutan 1 (1): 1-13. [Indonesian]

Moya R, Munoz F. 2010. Physical and mechanical properties of eight fastgrowing plantation species in Costa Rica. J Trop For Sci 22 (3): 317 328.

Mugasha WA, Bollandsas OM, Eid T. 2013. Relationships between diameter and height of trees in natural tropical forests in Tanzania. $\mathrm{J}$ For Sci 75 (4): 221-237.

Muttaqin Z, Cahyananto A, Panjaitan PBP. 2019. Hubungan penampilan tegakan jati trubusan umur tiga tahun dan sifat fisik tanah. In: Paembonan SA, Mansur I, Husna, Tuheteru FD, Arif A, Albasri (eds) Penerapan silvikultur untuk pengelolaan hutan dan pengentasan kemiskinan. Prosiding Seminar Nasional Silvikultur VI. Faculty of Forestry and Environment, Halu Oleo Universty, Kendari, 8-9 August 2018. SEAMEO BIOTROP Publication No. 73. [Indonesian]

Naji HR, Sahri MH, Nobuchi1 T, Bakar ES. 2011. The effect of growth rate on wood density and anatomical characteristics of rubberwood 
(Hevea brasiliensis Muell. arg.) in two different clonal trails. J Nat Prod Plant Resour 1 (2): 71-80.

Olivar J, Rathgeber C, Bravo F. 2015. Climate change, tree-ring width, and wood density of pines in Mediterranean environments. Intl Assoc Wood Anat 36 (3): 257-269.

Ozigi P, Jimoh A, Rahmon R et al. 2018. Investigation on some physical and mechanical properties of Apa (Afzelia bipindensis) timber grown in Kwara State, Nigeria. J Res Inf Civ Eng 15 (1): 2027-2044.

Pertiwi YAB, Aiso H, Ishiguri $F$ et al. 2017. Effect of radial growth rate on wood properties of Neolamarckia cadamba. J Trop For Sci 29 (1): 30-36.

Rachmawati Y, Daryono BS, Ariestya GR 2018. Phenotypical characters of melon (Cucumis melo L.) in response to karst critical land. J Trop Biol 2 (1): 1-11.

Rahmadwiati R, Sadono R, Supriyatno N. 2012. Preliminary stand table for average dominant trees of Jati Plus Perhutani in Saradan, Madiun, and Ngawi Forest Districs. J Trop For Manag 22 (1): 57-64.

Rizanti DE, Darmawan W, George B, et al. 2018. Comparison of teak wood properties according to forest management: short versus long rotation. Ann For Sci 75 (2): 39.

Rizki M, Fernandes A. 2015. Correlation between wood density and fiber length with essential macro-nutrients on base of stem of Shorea leprosula and Shorea parvifolia. KnE Life Sci 2: 625-629.

Rocha MFV, Veiga TRLA, Soares BD, Araujo ACC, Carvalho AMM, Hein PRG. 2019. Do the growing conditions of trees influence the wood properties? Floresta Ambient 26 (3). DOI: 10.1590/21798087.035318.

Rodriguez HG, Maiti R, Kumari A, et al. 2016. Variability in wood density and wood fibre characterization of woody species and their possible utility in northeastern Mexico. Am J Plant Sci 7: 1139-1150.

Shamaki SB, Akindele SO, Isah AD, Mohammed I. 2016. Heightdiameter relationship models for teak (Tectona grandis) plantation in Nimbia Forest Reserve, Nigeria. Asian J Environ Ecol 1 (1): 1-7.

Shmulsky R, Jones PD. 2019. Forest Products and Wood Science. An Introduction. John Wiley \& Sons, Inc., UK.
Sousa VB, Cardoso S, Quilho T, Pereira H. 2012. Growth rate and ring width variability of teak, Tectona grandis (Verbenaceae) in an unmanaged forest in East Timor. Rev Biol Trop 60 (1): 83-94.

Sumida A, Miyaura T, Torii H. 2013. Relationships of tree height and diameter at breast height revisited: analyses of stem growth using 20year data of an even-aged Chamaecyparis obtusa stand. Tree Physiol 33: 106-118.

Tardieu F, Parent B, Caldeira CF, Welcker C, 2014. Genetic and physiological controls of growth under water deficit. Plant Physiol J 164 (4): 1628-1635.

Tewari V, Mariswamy KM. 2013. Heartwood, sapwood and bark content of teak trees grown in Karnataka, India. J For Res 24 (4): 721-725.

Thulasidas P, Bailleres H. 2017. Wood quality for advanced uses of teak from natural and planted forests. IUFRO World Ser 36: 73-81.

Toledo M, Poorter L, Claros M, et al. 2011. Climate is a stronger driver of tree and forest growth rates than soil and disturbance. J Ecol 99: 254264.

Vospernik S, Monserud RA, Sterba H. 2010. Do individual-tree growth models correctly represent height: diameter ratios of Norway spruce and Scots pine? For Ecol Manag 260 (10): 1735-1753.

Widiatmaka W, Mediranto A, Widjaja H. 2015. Karakteristik, klasifikasi tanah, dan pertumbuhan tanaman jati (Tectona grandis Linn f.) Var. Unggul Nusantara di Ciampea, Kabupaten Bogor. J Pengelolaan Sumberd Alam Lingk 5 (1): 87-97. [Indonesian]

Yang B, Jia H, Zhao Z, et al. 2020. Horizontal and vertical distributions of heartwood for teak plantation. Forest 11 (2): 225-237.

Yulianti AD, Wahyudi I, Siregar IZ, Pari G. 2011. Wood quality of clones teak with different planting distance. J Ilmu Teknol Kayu Trop 9 (1): 93-100. [Indonesian]

Zahabu E, Raphael T, Chamshama SAO, Iddi S, Malimbwi RE. 2015. Effect of spacing regimes on growth, yield, and wood properties of Tectona grandis at Longuza forest plantation, Tanzania. Intl J For Res 26 (3): 1-16. 